\title{
Глава 3.
}

\section{СЕЛЕКЦИЯ И СЕМЕНОВОДСТВО}

\section{НАУЧНОЕ НАСЛЕДИЕ \\ СЕЛЕКЦИОНЕРОВ-ПЛОДОВОДОВ \\ ДОКТОРА СЕЛЬСКОХОЗЯЙСТВЕННЫХ НАУК \\ С. Ф. ЧЕРНЕНКО И ДОКТОРА СЕЛЬСКОХОЗЯЙСТВЕННЫХ \\ НАУК Е. С. ЧЕРНЕНКО И ПЕРСПЕКТИВЫ ИСПОЛЬЗОВАНИЯ ИХ СЕЛЕКЦИОННЫХ ДОСТИЖЕНИЙ В СОВРЕМЕННОМ САДОВОДСТВЕ}

Будаговская Н. В.

\begin{abstract}
Московский государственный университет им. М.В. Ломоносова, 2. Москва, Россия, e-mail: postnabu@mail.ru
\end{abstract}

Статья посвящена описанию научного наследия талантливых учёных, селекционеров - доктора сельскохозяйственных наук, профессора Семёна Федоровича Черненко и доктора сельскохозяйственных наук, профессора Екатерины Семёновны Черненко, авторов большого количества ценных высоковитаминных и устойчивых к неблагоприятным факторам среды сортов яблони и груши, получивших широкое распространение как в нашей стране, так и за рубежом. Рассматриваются перспективы использования селекционных достижений С. Ф. Черненко и Е. С. Черненко в современном садоводстве.

Ключевые слова: С. Ф. Черненко, Е. С. Черненко, плодоводство, селекция, сорта, яблоня, груша.

Сохранение богатого генофонда отечественных сортов плодовых культур является важной задачей современного садоводства. Отечественные сорта создавались с учётом климатических условий определённых регионов страны, хорошо адаптированы к ним, изучены их биологические особенности. Сохранение сортов отечественной селекции важно, как для проведения селекционной работы при использовании их в качестве доноров полезных признаков, так и для создания высокопродуктивных садовых насаждений. Большое количество отечественных сортов хорошо себя зарекомендовало в промышленных садах. Сохранение сортов плодовых культур может осуществляться в коллекциях научных и учебных учреждений, ботанических садах, генетических банках, в садах государственных и частных хозяйств. Чтобы не утратить сорта селекции прежних лет, необходимо проводить работы по их размножению и включению в новые садовые насаждения, а 
также для реализации с целью распространения. В этом ответственность сотрудников учреждений, в которых создавались сорта, других организаций, занимающихся садоводством, а также всех, кого заботит судьба отечественного садоводства.

Опытные плодоводы-селекционеры доктор сельскохозяйственных наук С. Ф. Черненко и доктор сельскохозяйственных наук Е. С. Черненко посвятили многие годы кропотливого труда созданию сортов яблони и груши с высокими хозяйственно-ценными свойствами. Их сорта прошли государственное сортоиспытание, районированы, получили высокие оценки специалистов.

В данной статье представлены материалы о научно-исследовательской и селекционной работе этих известных учёных.

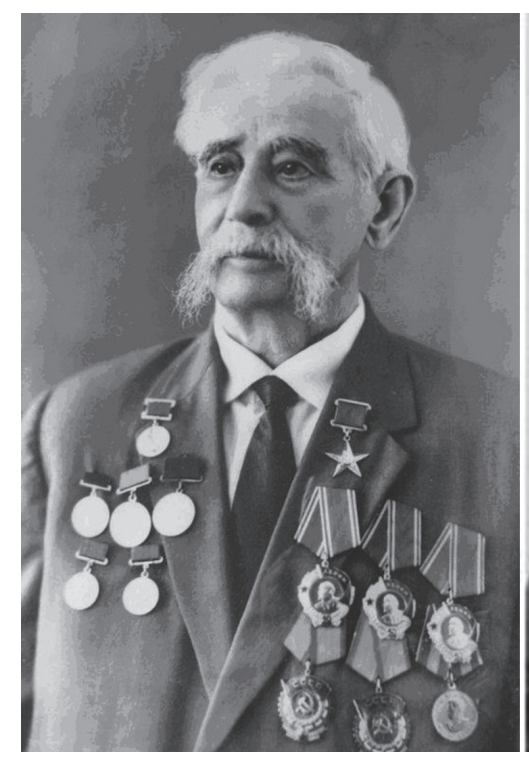

профессор С. Ф. Черненко, доктор сельскохозяйственных наук

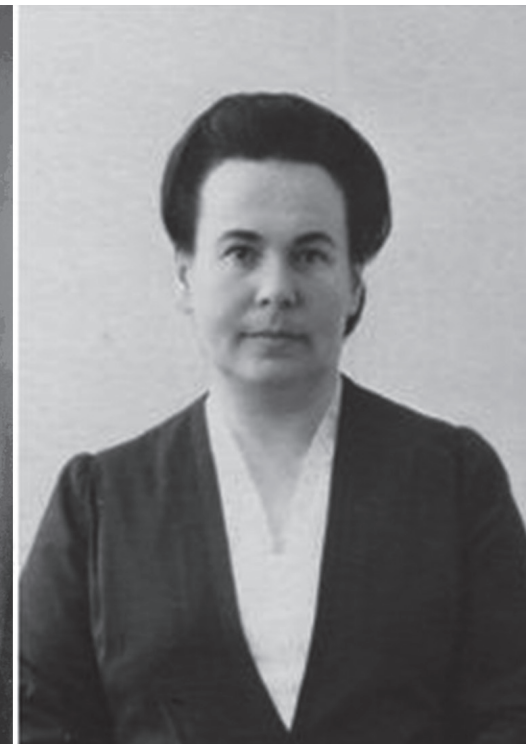

профессор Е. С. Черненко доктор сельскохозяйственных наук

\section{Научная и селекционная деятельность доктора сельскохозяйственных наук, профессора С.Ф. Черненко}

Доктор сельскохозяйственных наук, профессор С. Ф. Черненко создал много ценных сортов яблони и груши $[5-8,10,12,15,16]$. Он является автором знаменитого «Яблоневого календаря» - большого количества сортов яблони с разными сроками созревания: от раннелетних до позднезимних, охватывающих все месяцы года по времени созревания и готовности к потреблению. Некоторые из сортов яблони селекции С. Ф. Черненко, составляющие «Яблоневый календарь»: 
- летние - 'Июльское', 'Превосходное розовое', 'Память Шевченко', 'Грушовка новая', 'Смена', 'Радость', 'Юннатка';

- раннеосенние - 'Бархатное', 'Налив алый';

- осенние - 'Мичуринец', 'Нарядное', 'Тамбовское', 'Обильное', 'Прогресс', 'Первенец’, 'Выставочное', 'Подарок', ‘Богдан Хмельницкий', ‘Титфлер', 'Нежное', ‘Фиолетовое', 'Улыбка осени’;

- зимние - 'Анис апортовый', 'Антоновка новая', 'Богатырь', 'Боровинка ананасная', 'Великан', ‘Диана', ‘Звездочка', 'Кандиль северный', 'Катирен', 'Награда', 'Оранжевое', 'Память учителя', 'Пепин Черненко', 'Победа', 'Ренет Черненко', 'Суворовец', 'Успех’, 'Феникс', 'Фиолетовое', 'Шафранное'.

Это неполный список сортов «Яблоневого календаря Черненко».

Интересно отметить, что название сорту селекции С. Ф. Черненко 'Пепин Черненко' дал И. В. Мичурин и оценил его как «перворазрядный сорт», «перворазрядный выставочно-торговый сорт», поставил оценку 5. Сохранился автограф И. В. Мичурина с описанием этого сорта (рис. 1).

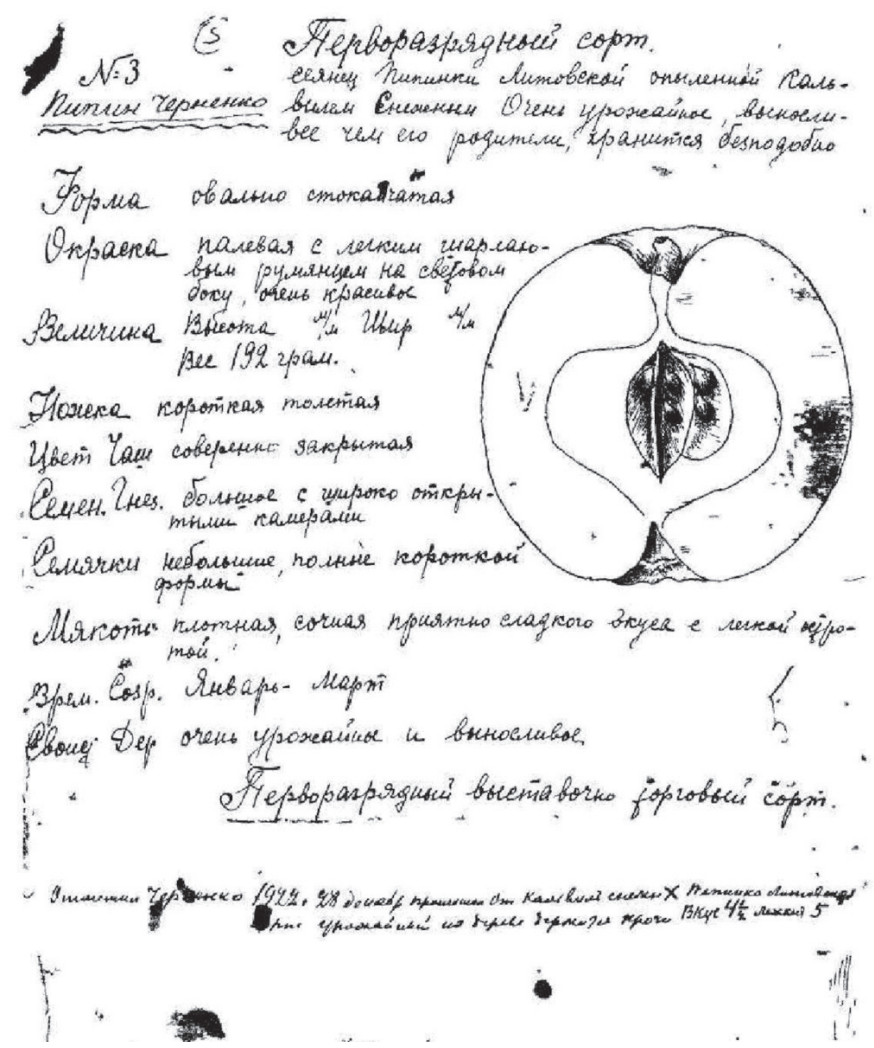

Рис. 1. Автограф И.В. Мичурина 1925 г.:

описание гибрида яблони № 3 селекции С. Ф. Черненко, присвоение ему названия 'Пепин Черненко' 
Сорт С. Ф. Черненко ‘Пепин Черненко’ ценится плодоводами и в настоящее время. Помимо очень хороших вкусовых качеств, он обладает высокой устойчивостью к парше и имеет ряд других достоинств [1]. Красивые плоды этого сорта были представлены на выставке, посвященной 160-летию И. В. Мичурина в 2015 г. (рис. 2).

Многие сорта яблони селекции С.Ф. Черненко используются в промышленных садах. Производственники ценят их за хороший вкус, высокую урожайность, скороплодность, зимостойкость, устойчивость к парше и другим грибным заболеваниям, высокое содержание витамина C, хорошую лёжкость плодов. Самым продуктивным промышленным сортом с красивыми вкусными, крупными плодами, хорошо хранящимися до лета, иногда до нового урожая, считается сорт С. Ф. Черненко 'Богатырь' (рис. 3). Это один из наиболее лёжких сортов $[10,12]$.

Среди сортов груши селекции С. Ф. Черненко специалисты отмечают как выдающийся по красоте крупных плодов и их вкусовым качествам, устойчивости к грибным заболеваниям, скороплодный и высокоурожайный сорт 'Красавица Черненко' (рис. 4). Сорт включен в Госреестр. Из других сортов груши, созданных С. Ф. Черненко, можно также отметить 'Подарок столетию' (к 100-летию И. В. Мичурина), 'Тамбовчанка', ‘Любимица Мичуринска', 'Бергамот Тамбовский', 'Достижение', 'Новоселка', 'Изящная', 'Кубаревидная' (неполный список), отличающиеся сроками созревания: от раннеосенних до позднеосенних $[6,12,15]$.

Также Семеном Федоровичем получены межродовые гибриды (груша $\times$ яблоня) и (яблоня $\times$ груша), которые вызвали большой интерес академика Н. И. Вавилова $[12,13,15]$. Эти гибриды сохранились до настоящего времени, имеют высокую зимостойкость и хорошее плодоношение [2] (рис. 5).

По данным журнала «Садоводство», в Мичуринске С. Ф. Черненко вывел 140 сортов [5]. Помимо этого, до переезда в Мичуринск он уже имел 16 сортов яблони и 1 сорт груши $[12,15]$.

Сорта С. Ф. Черненко районированы во многих областях. Они отличаются высоким содержанием витаминов и других биологически активных веществ. Некоторые сорта С. Ф. Черненко (например, 'Ренет Черненко' и др.) по содержанию витамина С в несколько раз превосходят эталонный сорт 'Антоновка'. Профессор Л. А. Вигоров, создавший в Свердловске «Сад лечебных культур», обнаружил в плодах сорта 'Ренет Черненко' высокое содержание Р-активных веществ и прислал Семёну Федоровичу поздравительную телеграмму от конференции в связи с этим. Сорта С. Ф. Черненко имеют высокую зимостойкость, они выдерживают не только климатические условия центральной части России с холодными зимами и перепадами температур, но и суро- 
вый климат севера нашей страны, Сибири, Поволжья с его контрастными погодными условиями. В Карелии на о. Валаам в северной части Ладожского озера летний сорт 'Июльское' селекции С. Ф. Черненко хорошо себя чувствует, не вымерзает. Некоторые сорта С. Ф. Черненко (например, 'Богатырь' и 'Ренет Черненко') предложено использовать в качестве эталонных по зимостойкости [17].
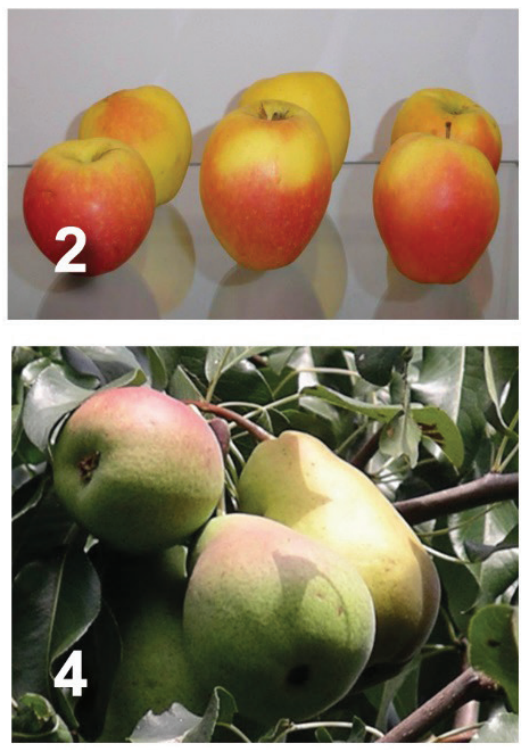

Рис. 2. Сорт яблони 'Пепин Черненко' селекции С.Ф. Черненко на выставке, посвященной 160 -летию

И. В. Мичурина B 2015 г.
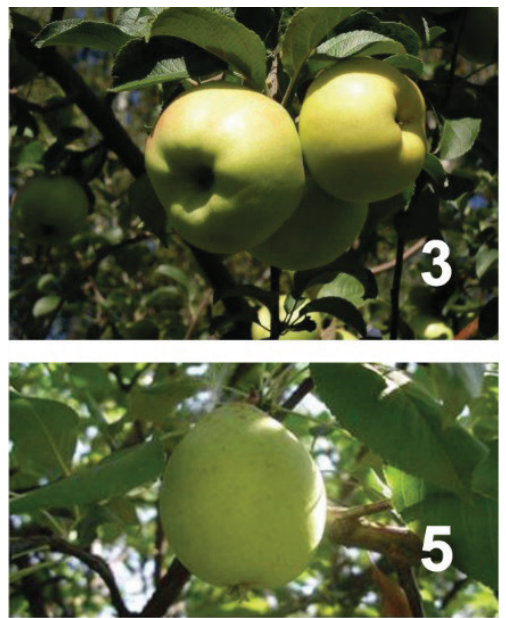

Рис. 3.

Сорт яблони 'Богатырь' селекции С. Ф. Черненко

Puc. 4.

Сорт груши 'Красавица Черненко' селекции С.Ф. Черненко

Pис. 5.

Гибрид (груша × яблоня) селекции С.Ф. Черненко. Прививка в крону груши сорта 'Красавица Черненко'

Обладая большим диапазоном устойчивости, сорта С. Ф. Черненко хорошо адаптируются в разных климатических зонах, включая северные (Новгородская, Тверская области, Карелия), западные, восточные (Сибирь), южные (Краснодарский край, Ставрополье) регионы нашей страны и ближнего зарубежья (Армения, Казахстан, Украина, Молдавия, страны Прибалтики и др.), а также страны дальнего зарубежья. В садах Чехословакии 26 сортов Семена Федоровича хорошо себя зарекомендовали. Президент академии сельскохозяйственных наук Чехословакии Антонин Клечка в знак уважения к С. Ф. Черненко за его научные достижения пригласил его посетить академию в Праге и институты садоводства в стране и лично сопровождал его в этой поездке. 
Семён Федорович смог сам убедиться, что его сорта прекрасно адаптировались в Чехословакии и сады с его сортами дают высокие урожаи [14]. Результаты селекционной работы С. Ф. Черненко получили международное признание.

На ВДНХ в Москве, где были представлены лучшие достижения страны в области науки, техники, сельского хозяйства и других отраслей народного хозяйства, около павильона «Садоводство» был посажен сад сортов С. Ф. Черненко и ежегодно осенью его сорта экспонировались на выставке плодов в этом павильоне.

За выдающиеся достижения по созданию новых сортов яблони и груши С. Ф. Черненко был удостоен высоких правительственных наград: трёх орденов Ленина, двух орденов Трудового Красного Знамени, золотой медали «Серп и молот», награждён Большими золотыми и серебряными медалями ВДНХ СССР, получил звания Лауреата Государственной премии СССР, Героя Социалистического труда $[5,8,16]$.

Результаты научных исследований, методы селекционной работы С. Ф. Черненко отражены в его многочисленных статьях и нескольких книгах. Свой многолетний опыт С. Ф. Черненко обобщил в книге «Полвека работы в саду» [14].

Помимо селекционной и научно-исследовательской работы, С. Ф. Черненко многие годы вёл педагогическую работу в плодоовощном институте им. И. В. Мичурина в качестве преподавателя, позже - доцента, профессора. В этом институте он был заведующим кафедрой селекции, генетики и сортоведения $[8,16]$.

Кроме научной и педагогической деятельности С. Ф. Черненко принимал активное участие в научно-организационной и общественной работе. Он являлся главным редактором журнала «Вестник плодовоягодных культур», членом редколлегии журнала «Вестник сельскохозяйственной науки», был членом Высшей аттестационной комиссии СССР (ВАК) при комитете по делам высшей школы, членом Технического совета Министерства земледелия СССР, членом научных советов министерства сельского хозяйства СССР и РСФСР, депутатом Верховного Совета РСФСР в течение десяти лет, участвовал в работе областного комитета защиты мира [8].

Сорта яблони и груши С. Ф. Черненко высоко ценятся плодоводами, они и в настоящее временя используются в промышленных садах, садах научно-исследовательских учреждений.

Обе дочери Семёна Федоровича Черненко - Юлия Семёновна и Екатерина Семёновна, как и их отец, стали успешными селекционерами-плодоводами. Старшая дочь, Юлия Семёновна Черненко, после окончания Плодоовощного института им. И. В. Мичурина занялась се- 
Глава 3. Селекция и семеноводство

лекцией южных культур. Она является автором и соавтором вместе со своим мужем, селекционером Федором Михайловичем Зориным, ряда ценных сортов и гибридов инжира, мандарина, сливы. Созданные ими сорта на Сочинской опытной станции субтропических и южных плодовых культур (в дальнейшем НИИ Горного садоводства и цветоводства, в настоящее время Всероссийский НИИ цветоводства и субтропических культур) прошли государственное сортоиспытание, районированы. Они произрастают и в настоящее время в садах субтропической зоны Черноморского побережья Кавказа. Кроме того, Ф. М. Зорин является создателем знаменитого «Дерева Дружбы» и многочисленных деревьев-садов с прививками разнообразных цитрусовых, положивших начало ботаническому саду, 85-летний юбилей которому отмечается в этом году, а ВНИИ цветоводства и субтропических культур отмечает 125-летний юбилей.

\section{Научная и селекционная деятельность доктора сельскохозяйственных наук, профессора Е. С. Черненко}

Екатерина Семёновна Черненко после окончания биологического факультета МГУ (Московский Государственный Университет), как и запланировала еще на первом курсе, поступила на работу в Центральную генетическую лабораторию им. И. В. Мичурина (с 1934 г, ЦГЛ имеет статус научно-исследовательского института в составе ВАСХНИЛ) в секцию селекции семечковых культур, чтобы заниматься селекцией яблони, как и её отец и работать вместе с ним, помогая ему. Помогать отцу она обещала И. В. Мичурину. «Мне приятно, что обещание, данное мною в детстве Мичурину, выполнено», отметит Екатерина Семёновна в воспоминаниях [12]. Позже Екатерина Семёновна поступила в аспирантуру в Плодоовощной институт им. И. В. Мичурина на кафедру селекции, генетики и сортоведения. После защиты кандидатской диссертации на тему: «Изменение возрастных признаков у сортов различной скороспелости» продолжила работу в секции селекции семечковых культур ЦГЛ, которой заведовал её отец, опытный селекционер, Семён Фёдорович Черненко. В исследовательской работе Екатерина Семёновна использовала анатомические, биохимические и физиологические методы в изучении новых сортов С. Ф. Черненко, а также занималась самостоятельной селекционной работой. Кроме этого, Екатерина Семёновна многие годы проводила исследования малоизученного явления - разнокачественности тканей у яблони, что было отражено в её докторской диссертации «Онтогенетические особенности яблонь корневого и стеблевого происхождения», которую она успешно защитила 
в Ленинградском сельскохозяйственном институте в 1971 г. В 1973 г. ей было присвоено звание профессора.

Екатерина Семёновна уделяла большое внимание педагогической работе. В должности заведующей кафедрой ботаники МГПИ Екатерина Семёновна проработала 28 лет. Она сформировала кафедру, организовала две биостанции, читала лекции по курсу ботаники (анатомия и морфология растений) и по плодоводству, проводила практические занятия и полевую практику со студентами, обучала студентов методам работы в саду, руководила научными работами студентов и аспирантов. Екатерина Семёновна обучала также студентов пединститута организации школьных садов, проводила беседы и практические занятия в саду со школьниками и учителями. Она понимала, что школьные сады - важный фактор в воспитании учащихся [9]. В целях сохранения генофонда сортов яблони и груши Екатерина Семеновна собрала на биостанции коллекцию представителей этих культур.

Педагогической и научной работе в МГПИ Екатерина Семёновна посвятила 57 лет. Общий стаж научно-исследовательской работы Екатерины Семёновны составил 67 лет. Екатерина Семёновна автор большого количества научных, научно-популярных статей и пяти книг.

Так же, как и её отец, Екатерина Семеновна посвятила свою жизнь саду. Это научная, педагогическая, селекционная и практическая работа.

Для выведения новых сортов Е. С. Черненко использовала сорта яблони селекции С. Ф. Черненко, обладающие богатой наследственностью. Сорта селекции С. Ф. Черненко являются ценными донорами хозяйственно-полезных признаков $[1,6,10,11,17]$.

По оценкам доктора с.-х. наук И. С. Исаевой, «все сорта Е. С. Черненко отличного вкуса, с красивыми, яркими плодами, урожайны, устойчивы к парше и с достаточной для средней полосы зимостойкостью. Но главное, что при этом, например, 'Десертное Будаговского' и 'Памяти Будаговского' оказались чемпионами по содержанию витамина $\mathrm{C}$, для того, чтобы получить суточную норму витамина С (50-70 мг) достаточно съесть одно яблоко 'Памяти Будаговского' или же 4 яблока Антоновки обыкновенной [3]. Следует отметить, что 'Антоновка' считается эталонным сортом по содержанию витамина С. В отличие от 'Антоновки', сорта Е. С. Черненко некислые, в них хорошо сбалансировано содержание сахаров и кислот.

Сорта Е. С. Черненко хорошо зарекомендовали себя в сложных климатических условиях Поволжья с морозными зимами и летней засухой. По данным С. В. Звонникова, сорта Е. С. Черненко не вымерзали в Самарской области при тридцатипятиградусных морозах и проявляли засухоустойчивость в летний период [4]. 
Приводим краткое описание сортов селекции Е. С. Черненко по материалам сортоизучения $[3,11]$. Эти сорта зарегистрированы Государственной комиссией Российской Федерации по испытанию и охране селекционных достижений.

Летний сорт 'Десертное Будаговского' (рис. 6). Екатерина Семёновна посвятила этот сорт мужу, Валентину Ивановичу Будаговскому, селекционеру-плодоводу, автору большого количества зимостойких карликовых и полукарликовых подвоев яблони и организатору промышленного карликового садоводства в нашей стране. Зимостойкость сорта 'Десертное Будаговского' более высокая, чем у 'Антоновки обыкновенной’, раннее плодоношение, обильная урожайность. Плоды довольно крупные с яркой окраской, нежной сочной мякотью, десертным сладко-кислым вкусом с гармоничным сочетанием сахара и кислоты, имеют тонкий аромат. На слаборослых подвоях В. И. Будаговского плодоношение наступает рано, через два года после посадки. В питомнике зацветают однолетки. Деревья имеют сдержанный рост. Экономический эффект от использования сорта больше, чем от сорта 'Мельба'. Сорт устойчив к парше и тле.

Зимний сорт 'Память Черненко' (посвящён памяти С. Ф. Черненко) (рис. 7 и 8). Имеет высокую зимостойкость и устойчивость к засухе. На карликовых подвоях плодоношение наступает рано, на второй год после посадки, в питомнике зацветают однолетки. Урожайность обильная, плоды эффектными гроздями висят на ветвях и не опадают. Размер плодов: выше средней величины и крупные. Форма плодов красивая, коническая. Окраска нарядная, тёмно-красная, размытая почти по всей поверхности. Сильный восковой налёт придает ей особую прелесть. Мякоть сочная, искристая, нежная, приятного сладко-кислого вкуса со сбалансированным сочетанием сахара и кислоты. По оценке помологических комиссий, вкус заслуживает высокой оценки. Плоды хорошо лежат до лета даже в неспециализированных хранилищах. Хорошая транспортабельность плодов, имеющиеся нажимы не загнивают. Назначение сорта - универсальное. Экономический эффект от использования сорта больше, чем от 'Антоновки обыкновенной'.

Зимний сорт 'Памяти Будаговского' (рис. 9). Крупноплодный, хороший вкус, высокая урожайность, хорошая сохранность плодов в течение 7-8 месяцев. По данным ВНИИ садоводства им. И. В. Мичурина из 42 изучавшихся сортов сорт 'Памяти Будаговского' обнаружил лучшие результаты по хранению. Плоды имеют нарядную окраску - по светло-кремовому фону яркие красные штрихи. Мякоть плодов белая, очень сочная, плотная, мелкозернистая. Вкус кисло-сладкий, приятный, с тонким приятым ароматом, с гармоничным сочетанием сахара 
и кислоты. Транспортабельность плодов хорошая. Назначение сорта - универсальное. Плодоношение наступает рано, на третий год после окулировки, в питомнике зацветают однолетки. Устойчивость к морозам очень высокая, к засухе и грибным заболеваниям - высокая.
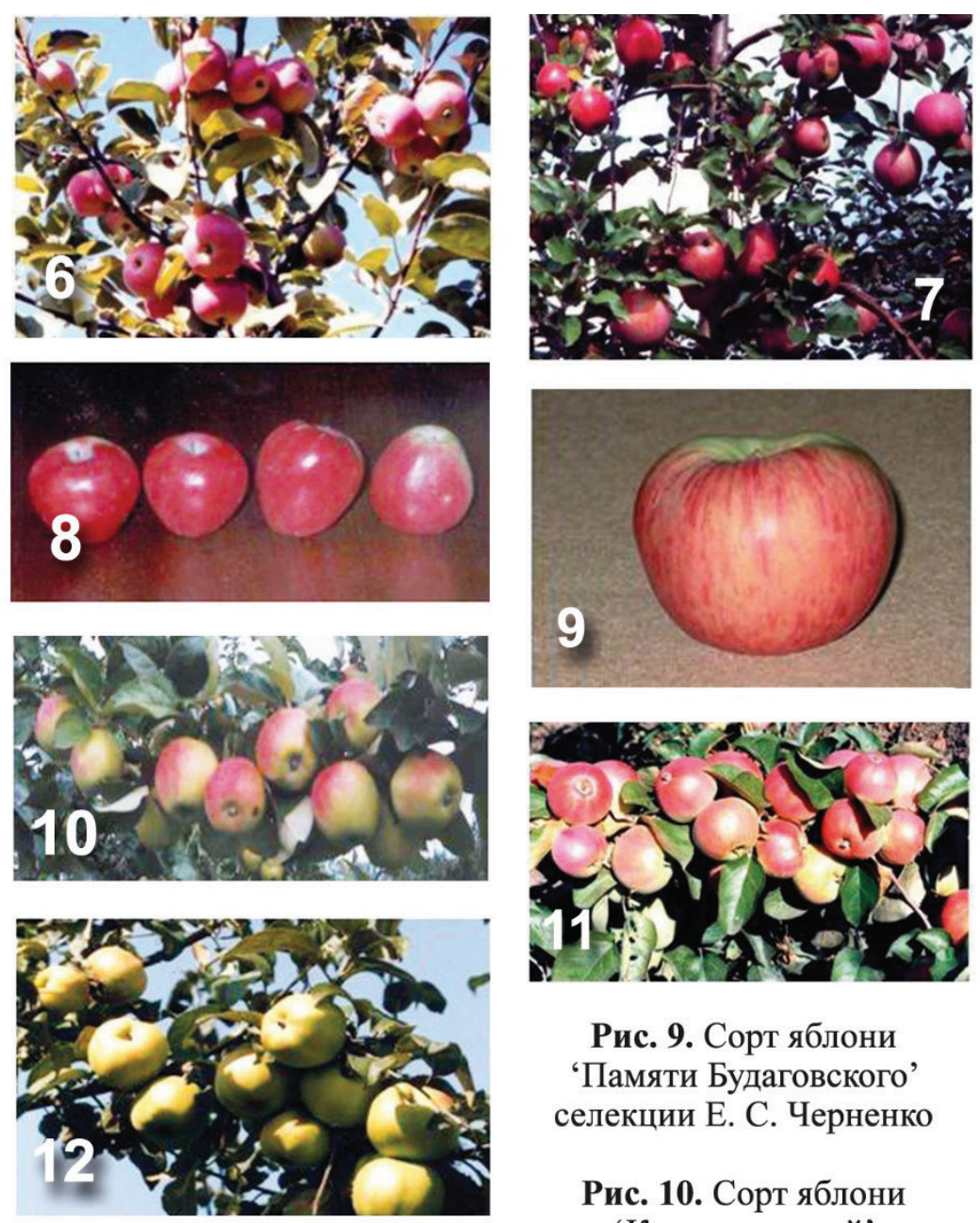

Рис. 9. Сорт яблони 'Памяти Будаговского' селекции Е. С. Черненко

Рис. 10. Сорт яблони 'Кандиль новый'

Рис. 6. Сорт яблони 'Десертное Будаговского' селекции Е. С. Черненко

Рис. 7 и 8. Сорт яблони 'Память Черненко' селекции Е. С. Черненко селекции Е. С. Черненко

Рис. 11. Сорт яблони

'Полинка' селекции Е. С. Черненко

Рис. 12. Сорт яблони 'Кальвиль золотистый' селекции Е. С. Черненко 
Глава 3. Селекция и семеноводство

Зимний сорт 'Кандиль новый' (рис. 10). Скороплодный, урожайный, зимостойкий, обладает высокой иммунностью. Плоды по вкусу не уступают лучшим южным сортам. Плоды очень красивые с алым румянцем по светло-кремовому фону. Размер плодов от среднего до крупного. Мякоть белая, плотная, сочная, приятного кисло-сладкого вкуса. Лежать плоды могут до весны. Деревья сдержанного роста. Нарядные плоды, густо расположенные на ветвях, образуют эффектные гирлянды. Плодоносящее дерево очень красиво.

Зимний сорт 'Полинка' (рис. 11). Сорт скороплодный, очень урожайный. В благоприятные годы плоды так плотно сидят на ветках, что напоминают облепиху. В питомнике зацветают однолетки. Размер плодов средний, но может быть и довольно крупный. Окраска нарядная, ярко-вишнёвая. Мякоть белая, плотная, сочная, кисло-сладкая, приятная. Деревья сдержанного роста, крона овальная, листья округлые, напоминают форму плода. Сорт имеет хорошую зимостойкость.

Зимний сорт 'Кальвиль золотистый' (рис. 12). Плоды крупные, светло-жёлтые, на солнечной стороне с лёгким загаром. Мякоть белая, плотная, сочная, сладко-кислая, приятная. Сохраняться плоды могут до весны. Деревья средней силы роста с округлой кроной и прочным скреплением ветвей. Зимостойкость хорошая.

Сорта Е. С. Черненко, как и сорта С. Ф. Черненко, которые были использованы Екатериной Семёновной в селекционной работе, обладают комплексом качеств, которые высоко ценятся в плодоводстве.

Заключение. Сорта селекции С. Ф. Черненко и Е. С. Черненко имеют высокие вкусовые качества, красивы, иммунны, зимостойки, устойчивы к засухе и резким перепадам температуры, богаты витаминами и другими биологически активными веществами, хорошо хранятся, по готовности к потреблению охватывают все месяцы года. Сорта этих селекционеров прошли испытание временем в разных регионах РФ и за рубежом. Эти сорта используются в современном садоводстве. Сорта селекции С. Ф. Черненко и Е. С. Черненко являются донорами хозяйственно-полезных признаков, с их участием были получены перспективные сорта, они и в дальнейшем могут быть использованы в селекционной работе $[1,6,7,10,17]$. Очень важно сохранять селекционные достижения отечественных ученых-селекционеров, посвятивших свои жизни созданию ценных сортов.

\section{Библиографический список}

1. Андреева Н.В., Полянский Н.А., Бобрович Л.В. К вопросу возможности использования сортов яблони С. Ф. Черненко в дальнейшей селекции на повышение устойчивости плодовых растений к факторам среды // Перспективы селекции яблони и 
других культур для промышленных насаждений: материалы Всероссийской научнопрактической конференции, посвященной 130 -летию со дня рождения профессора С. Ф. Черненко, Мичуринск, 21-23 ноября 2007 г. - Мичуринск-наукоград РФ: МичГАУ, 2007. - C. 229-232. - ISBN 978-5-94664-129-6.

2. Будаговская Н.В. Биологические особенности межродового груше-яблоневого гибрида селекции С. Ф. Черненко // Новые и нетрадиционные растения и перспективы их использования: материалы XIII Международной конференции, Сочи, 4-8 июня 2018 г. - М.: РУДН, 2018. - С. 357-362. - ISBN 978-5-209-08756-4.

3. Исаева И.С. Новейшие сорта яблони Екатерины Черненко // Своя дача. - 2003. № 2 (44), - С. 8-9.

4. Звонников С.В. Сад её жизни // Современные проблемы и перспективы отечественного садоводства: материалы межрегиональной научно-практической конференции, посвященной 90-летию со дня рождения профессора Е. С. Черненко. - МичуринскНаукоград РФ: МГПИ, 2009. - С. 92-94. - ISBN 978-5-9298-0353-6.

5. К 90-летию С. Ф. Черненко // Садоводство. - 1997. - № 9. - С. 46.

6. Савельев Н.И., Чивилев В.В. Развитие научного наследия И. В. Мичурина и С. Ф. Черненко по селекции груши // Перспективы селекции яблони и других культур для промышленных насаждений: материалы Всероссийской научно-практической конференции, посвященной 130-летию со дня рождения профессора С. Ф. Черненко, Мичуринск, 21-23 ноября 2007 г. - Мичуринск-наукоград РФ: МичГау, 2007. - С. 51-53. - ISBN 978-5-94664-129-6.

7. Самигуллина Н.С. Верность призванию // Перспективы селекции яблони и других культур для промышленных насаждений: материалы Всероссийской научно-практической конференции, посвященной 130 -летию со дня рождения профессора С. Ф. Черненко, Мичуринск, 21-23 ноября 2007 г. Мичуринск-наукоград РФ: МичГАУ, 2007. - C. 30-34. - ISBN 978-5-94664-129-6.

8. Черненко Е.С., Колесников В.А., Нестеров Я.С. Славный путь селекционера-плодовода. К 100-летию со дня рождения С. Ф. Черненко // Вестник с./х. науки. - 1978. - № 3. - С. 145-146.

9. Черненко Е.С. Школьный сад. - М: Просвещение, 1993. - 192 с. - ISBN 5-09-003982-8. 10. Черненко Е.С. Генофонд С. Ф. Черненко и его селекционное значение // Проблемы формирования генетических коллекций плодовых, ягодных культур и перспективы их селекционного использования: материалы XXI Мичуринских чтений, Мичуринск, 28-30 октября 2002 г. - Мичуринск, 2002. - Ч. 1. - С. 23. - ISBN 5-900665-31-3.

11. Черненко Е.С. Новые сорта яблони // 50 лет факультету биологии: итоги и перспективы: материалы научно-практической конференции, Мичуринск. 2002 г.: Мичуринск-Наукоград РФ: МГПИ, 2002. - С. 47-49.

12. Черненко Е.С. По пути И. В. Мичурина // Труды ВНИИГиСПР им. И.В. Мичурина. Генетика и селекция плодовых растений: сб. науч. трудов. - Воронеж: Кварта, 2005. - C. 243-257. - ISBN 5-89609-067-6.

13. Черненко Е.С. Незабываемые встречи // Реализация идей И.В. Мичурина в образовательном процессе: материалы научно-практической конференции, Мичуринск-Наукоград РФ, 2005 г.: - Мичуринск-Наукоград РФ: МГПИ, 2005. - С. 56-63. - ISBN 5-9298-0234-3.

14. Черненко Е.С. Сады Будаговского. - Мичуринск: МГПИ, 2005. - 480 с.

15. Черненко С.Ф. Полвека работы в саду. - М.: Сельхозгиз, 1957. - 503 с.

16. Черненко Семён Федорович // БСЭ. - М: Советская Энциклопедия. 1978. - T. 29. - C. 85.

17. Хаустович И.П. Сорта 'Ренет Черненко' и 'Богатырь' - эталон зимостойкости яблони в средней зоне России // Перспективы селекции яблони и других культур для промышленных насаждений: материалы Всероссийской научно-практической конференции, посвященной 130-летию со дня рождения профессора С.Ф. Черненко, Мичуринск, 21-23 ноября 2007 г. - Мичуринск-наукоград РФ: МичГау, 2007. - С. 240-243. - ISBN 978-5-94664-129-6. 


\title{
SCIENTIFIC HERITAGE OF FRUIT BREEDERS-DOCTOR OF AGRICULTURAL SCIENCES S. F. CHERNENKO AND DOCTOR OF AGRICULTURAL SCIENCES YE. S. CHERNENKO AND PERSPECTIVES OF USING THEIR BREEDING ACHIEVEMENTS IN MODERN HORTICULTURE
}

\author{
Budagovskaya N. V.
}

M.V. Lomonosov Moscow State University, c.Moscow, Russia, e-mail:postnabu@mail.ru

The paper is devoted to the description of scientific heritage of talented scientists, breeders - doctor of agricultural sciences, professor Semyon Chernenko and doctor of agricultural sciences, professor Yekaterina Chernenko, authors of a large number of valuable apple and pear cultivars, high-vitamin and resistant to unfavorable environmental factors, which are widely distributed both in our country and abroad. Perspectives of using their breeding achievements in modern horticulture are considered.

Key words: S. F. Chernenko, Ye. S. Chernenko, horticulture, breeding, cultivars, apple, pear. 